4

\title{
Precipitation of ordered dolomite via simultaneous dissolution of calcite and magnesite: New experimental insights into an old precipitation enigma
}

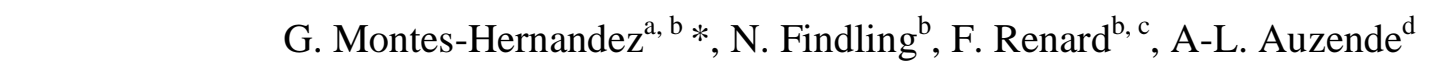

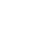

${ }^{\mathrm{b}}$ Univ. Grenoble Alpes, ISTerre, F-38041 Grenoble, France

${ }^{\mathrm{c}}$ PGP, University of Oslo, box 1048 Blindern, 0316 Oslo, Norway

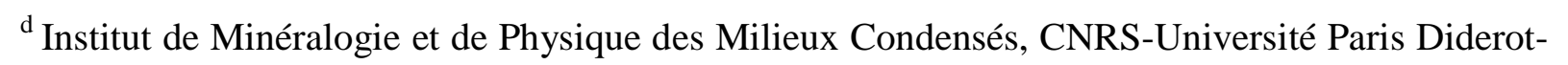
UPMC, F-75252 Paris, France

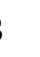

.

*Corresponding author: G. Montes-Hernandez

E-mail address: german.montes-hernandez@ujf-grenoble.fr

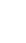
8 9 20 1 2 


\section{Abstract}

In the present study, we demonstrate that ordered dolomite can be precipitated via simultaneous dissolution of calcite and magnesite under hydrothermal conditions (from 100 to $200^{\circ} \mathrm{C}$ ). The temperature and high-carbonate alkalinity have significantly co-promoted the dolomite formation. For example, when high-purity water was initially used as interacting fluid, only a small proportion of disordered dolomite was identified at $200^{\circ} \mathrm{C}$ from XRD patterns and FESEM observations. Conversely, higher proportion of ordered dolomite, i.e. clear identification of superstructure ordering reflections in XRD patterns, was determined when high-carbonate alkalinity solution was initially used in our system at the same durations of reaction. For this latter case, the dolomite formation is favorable therefrom $100^{\circ} \mathrm{C}$ and two kinetic steps were identified (1) proto-dolomite formation after about five days of reaction, characterized by rounded sub-micrometric particles from FESEM observations and by the absence of superstructure ordering reflections at 22.02 (101), 35.32 (015), 43.80 (021), etc. 2thetha on XRD patterns; (2) proto-dolomite to dolomite transformation, probably produced by a coupled dissolution-recrystallization process. Herein, the activation energy was estimated to $29 \mathrm{~kJ} / \mathrm{mol}$ by using conventional Arrhenius linear-equation. This study provides new experimental conditions to which dolomite could be formed in hydrothermal systems. Temperature and carbonate alkalinity are particularly key physicochemical parameters to promote dolomite precipitation in abiotic systems. 
46 Keywords: Dolomite formation; High-carbonate alkalinity; Magnesite; Calcite; Crystal growth;

47 Hydrothermal systems.

48 


\section{Introduction}

The formation and textural properties of dolomite $\left(\mathrm{CaMg}\left(\mathrm{CO}_{3}\right)_{2}\right)$ have already been investigated in the past two centuries (1-4). However, various questions still remain unanswered concerning its formation mechanism and kinetics in natural systems as well as its synthesis in the laboratory. For example, the formation of ordered dolomite at ambient temperature is virtually impossible, possibly due to the high hydration nature of $\mathrm{Mg}^{2+}$ ions in solution at low temperature (4-6). Moreover, the scanty distribution of modern dolomite in nature contrasts strongly with its common abundance in ancient sedimentary rocks of marine origin, leading to the paradox commonly referred to as the "dolomite problem" (7-9). Experimental syntheses regarding the physicochemical conditions, reaction mechanisms and kinetics at which dolomite can be formed could resolve this paradox. Typically, the dolomite precipitation in laboratory has been investigated by reference to natural setting, in this way, three main kinds of experimental configurations have been carried out: (1) Direct and homogenous precipitation by mixing (fast or slowly) two pre-defined solutions, one containing $\mathrm{Mg} / \mathrm{Ca}$ ratio $(\geq 1)$ and other containing dissolved carbonate ions. This simple reaction pathway has only success at high temperature $\left(>100^{\circ} \mathrm{C}\right)(5,10)$. In the similar way, more sophisticated experimental setups have been built "hydrothermal flow reactors" to investigate the kinetic behavior of dolomite precipitation, but, these systems have systematically used pre-existent dolomite crystals "or seed material", this can indeed provide idealized or limited information on the overgrowth of dolomite (syntaxial and/or epitaxial growth) (9). (2) Calcite dolomitization by placing high-purity calcite or limestone material in contact with $\mathrm{Mg}$-rich solution. This calcite replacement by ordered dolomite is particularly favorable also at high temperature $\left(>100^{\circ} \mathrm{C}\right)(11-13)$. This reaction mechanism could 
71 explain the massive dolomite formation in sedimentary environments if such sediments are

72 submitted to significant temperature variations and/or to significant changes of pore-fluid

73 chemistry over geologic times (e.g. 14). (3) Bio-assisted dolomitization by using sulfate-reducing

74 or aerobic heterotrophic bacteria, hypersaline or seawater solutions and anoxic or oxic conditions

75 in controlled lab systems; these complex procedures seem to have success at low temperature to

76 synthesize dolomite as reported in various recent studies (2, 15-18); however, the provided

77 information has not shown convincing proof of the presence of ordered dolomite for these low-

78 temperature syntheses. For example, reported XRD patterns have not clearly shown the presence

79 of superstructure ordering reflections at $22.02(101), 35.32(015), 43.80(021)$, etc. 2thetha on

80 synthetized material as described by Lippmann (19). Moreover, the reaction mechanism and role

81 of all parameters (including culture media and/or cellular secretions) is poorly understood.

82 Identifying novel and/or innovative abiotic or biotic synthesis methods for dolomite at a broad spectrum of experimental conditions still remain a major scientific challenge to obtain a better understanding of its formation in natural systems and to facilitate its production at laboratory scale.

In this context, the present study has explored a new synthesis pathway for dolomite by 87 using calcite and magnesite as $\mathrm{Ca}$ and $\mathrm{Mg}$ sources, respectively $88\left(\mathrm{CaCO}_{3}+\mathrm{MgCO}_{3} \rightarrow \mathrm{CaMg}\left(\mathrm{CO}_{3}\right)_{2}\right)$. This reaction pathway has not been investigated to the best of our knowledge. However, calcite and magnesite could co-exist in various natural media

90 (sedimentary deposits, modern marine sediments, hydrothermal systems, deep geological 91 formations...). Moreover, this simple reaction pathway allows us determining if dolomite 92 formation is favorable via dissolution of its $\mathrm{Mg}$-rich and Ca-rich end-members under 
hydrothermal conditions in closed systems.

\section{Materials and Methods}

\subsection{Preparation of solid reactants}

97 Calcite: High-purity calcite characterized by nanosized $(<100 \mathrm{~nm})$ and sub-micrometric $(<1 \mu \mathrm{m})$

98 particles were synthesized by aqueous carbonation of portlandite $\left(\mathrm{Ca}(\mathrm{OH})_{2}\right)$. The specific procedure and fine calcite characterization have already been reported by Montes-Hernandez et al. (20).

Magnesite: Rhombohedral single crystals $(<2 \mu \mathrm{m})$ of magnesite were synthesized by two main sequential reactions: (1) aqueous carbonation of synthetic brucite $\left(\mathrm{Mg}(\mathrm{OH})_{2}\right)$ by injection of $\mathrm{CO}_{2}$ in a highly alkaline medium $(2$ molal of $\mathrm{NaOH})$ at ambient temperature $\left(\sim 20^{\circ} \mathrm{C}\right)$, leading to precipitation of platy-compacted aggregates of dypingite $\left(\mathrm{Mg}_{5}\left(\mathrm{CO}_{3}\right)_{4}(\mathrm{OH})_{2} .5 \mathrm{H}_{2} \mathrm{O}\right)$ after $24 \mathrm{~h}$; (2) complete dypingite-to-magnesite transformation after $24 \mathrm{~h}$ by a simple heat-ageing step from 20 to $90^{\circ} \mathrm{C}$. These synthesis pathways and magnesite characterizations have been previously reported by Montes-Hernandez et al. (21).

\subsection{Preparation of reacting solutions}

High-purity water with an electrical resistivity of $18.2 \mathrm{M} \Omega \mathrm{cm}(\mathrm{PW})$ and high-carbonate alkaline solution (HAS) were used as interacting solutions in the dolomitization experiments. The HAS was prepared by direct capture of $\mathrm{CO}_{2}$ in contact with a concentrated $\mathrm{NaOH}$ solution $(2 \mathrm{~m})$. Herein, 50bar of $\mathrm{CO}_{2}(\sim 2 \mathrm{~mol})$ were injected into the titanium reaction cell (2L of volume) at 
113 ambient temperature $\left(\sim 20^{\circ} \mathrm{C}\right)$. The $\mathrm{CO}_{2}$ consumption (or pressure drop of $\left.\mathrm{CO}_{2}\right)$ and temperature

114 (exothermic reaction) were in-situ monitored until a macroscopic equilibrium that was reached 115 after about $24 \mathrm{~h}$. Then, the residual $\mathrm{CO}_{2}$ gas was removed from reactor and the solution was 116 recovered by simple decanting of supernatant solution. Based on Solvay typical reactions, the 117 following global reactions are expected:

$$
2 \mathrm{NaOH}+\mathrm{CO}_{2} \rightarrow \mathrm{Na}_{2} \mathrm{CO}_{3}+\mathrm{H}_{2} \mathrm{O}
$$

$$
\mathrm{Na}_{2} \mathrm{CO}_{3}+\mathrm{H}_{2} \mathrm{O}+\mathrm{CO}_{2} \rightarrow 2 \mathrm{NaHCO}_{3}
$$

The X-ray diffraction on the recovered solid and the measurements in the solution $(\mathrm{pH}=8.7$ and total carbon $(\mathrm{TC})=0.95 \mathrm{M}$ ) have confirmed this above reactions.

\subsection{Dolomitization experiments}

123 Five Teflon reaction cells were loaded with $1.5 \mathrm{ml}$ of high-carbonate alkaline solution (HAS),

$124100 \mathrm{mg}$ of calcite and $100 \mathrm{mg}$ of magnesite. Five other reaction cells were loaded with the same

125 mineral amounts, but with $1.5 \mathrm{ml}$ of high-purity water (PW). All reaction cells (cap-cell also in

126 Teflon) were immediately assembled into independent steel mini-autoclaves without agitation,

127 referred to as "static batch reactor" and the closed autoclaves were placed in a multi-oven (ten

128 independent temperature compartments). This allowed the simultaneous investigation of five 129 independent temperatures $\left(50,75,100,150\right.$ and $\left.200{ }^{\circ} \mathrm{C}\right)$ and two different interacting solutions 130 (PW and HAS). The reaction duration for these ten experiments was arbitrarily imposed to 90 131 days. These exploratory experiments have revealed that ordered dolomite is preferentially formed 132 in carbonate alkaline medium therefrom $100^{\circ} \mathrm{C}$ for the investigated lapse of time. For this reason, 
133

134

135

136

137

138

139

140

141

142

143 144 described below.

145

146

147

148

149

150

151

152

153

154

complementary dolomitization experiments were performed using exclusively carbonate alkaline solution as interacting fluid in order to determine the dolomite precipitation rate. For this case, five reaction durations were arbitrarily imposed $(5,13,21,42$ and 62 days) at three different temperatures $\left(100,150\right.$ and $\left.200^{\circ} \mathrm{C}\right)$. We note that only two reaction durations (5 and 20 days) were considered for experiments at $100^{\circ} \mathrm{C}$. In all experiments, the same mineral amounts of reactants and volume of interacting solution were used. All experiments and some results are summarized in Table 1. At the end of the experiment, the autoclave was quenched in cold water. This manipulation limits a significant perturbation of the solid-reaction products with respect to a slow cooling process. Then, the autoclave was disassembled and the fluid was collected for $\mathrm{pH}$ measurement exclusively. Finally, the solid product was directly dried in the Teflon reaction cells at $90{ }^{\circ} \mathrm{C}$ for $24 \mathrm{~h}$. The dry solid product was recovered for further solid characterizations

\subsection{Characterization of solid products}

X-Ray Powder Diffraction (XRD) analyses were performed using a Siemens D5000 diffractometer in Bragg-Brentano geometry; equipped with a theta-theta goniometer with a rotating sample holder. The XRD patterns were collected using $\mathrm{Cu} k \alpha_{1}\left(\lambda_{\mathrm{k \alpha} \alpha}=1.5406 \AA\right)$ ) and $\mathrm{k} \alpha_{2}$ $\left(\lambda_{\mathrm{k} \alpha 2}=1.5444 \AA\right.$ ) radiation in the range $2 \theta=10-70^{\circ}$ with a step size of $0.04^{\circ}$ and a counting time of 6 seconds per step. Residual calcite and magnesite, dolomite and natrite minerals on XRD patterns were systematically refined by Rietveld method using the BGMN software and its associated database (22), except for run 5 where eitelite mineral was also added. The precipitation of this latter mineral was probably promoted by an unexpected micro-leakage in the system, which was confirmed at the end of experiment. 
FESEM observations: Selected samples containing dolomite were dispersed by ultrasonic

156

157

158

159

160 treatment in absolute ethanol for five to ten minutes. One or two droplets of the suspension were then deposited directly on an aluminum support for SEM observations, and coated with platinum. The morphology of crystal faces was observed by using a Zeiss Ultra 55 field emission gun scanning electron microscope (FESEM) with a maximum spatial resolution of approximately $1 \mathrm{~nm}$ at $15 \mathrm{kV}$.

TEM observations: one selected sample (from run 16) was shaken in ethanol for a short time in order to split the aggregates without any additional treatment. A drop of the suspension was deposited on a holey carbon foil and placed on a conventional copper micro-grids for further observations with JEOL 2100F Transmission Electron Microscope (TEM) operating at $200 \mathrm{kV}$, equipped with a field emission gun and a high-resolution pole piece achieving a point-to-point resolution of $1.8 \AA$. Chemical mapping was achieved by combining the scanning module of the microscope (STEM) to the EDS detector.

Thermogravimetric analyses: TGA for all solid products were performed with a Mettler Toledo TGA/SDTA 851e instrument under the following conditions: sample mass of about $10 \mathrm{mg}, 150$ $\mu \mathrm{l}$ alumina crucible with a pinhole, heating rate of $10^{\circ} \mathrm{C} \min ^{-1}$, and inert $\mathrm{N}_{2}$ atmosphere of $50 \mathrm{ml}$ $\min ^{-1}$. We note that all samples containing dolomite were also analyzed under $\mathrm{CO}_{2}$ atmosphere using the same flow $(50 \mathrm{ml} / \mathrm{min})$ in order to separate correctly the dolomite decomposition from magnesite and calcite decomposition in the samples. Sample mass loss and associated thermal effects were obtained by TGA/SDTA. In order to identify the different mass loss steps, the TGA first derivative (rate of mass loss) was used. The TGA apparatus was calibrated in terms of mass and temperature. Calcium oxalate was used for the sample mass calibration. The melting points 
177 of three compounds (indium, aluminum and copper) obtained from the DTA signals were used 178 for the sample temperature calibration. containing calcium and magnesium, respectively. Assuming that these two minerals could coexist in hydrothermal systems and other Earth or planetary systems, this study provides new experimental conditions to which the dolomite can be formed via simultaneous dissolution of calcite and magnesite. Obviously, this particular case could not explain the dolomite abundance in ancient sedimentary rocks of marine origin. X-ray diffraction results have revealed the formation of ordered dolomite therefrom $100^{\circ} \mathrm{C}$ when high-carbonate alkaline solution is used as interacting fluid. This was clearly identified by the presence of superstructure ordering reflections 101, 015, 021, etc. from 036-0426 pattern for dolomite (Figure 1). Conversely, small proportion of disordered dolomite was exclusively identified at $200^{\circ} \mathrm{C}$ whether high-purity water is used as interacting fluid for the same duration of reaction (90 days) (Figure 1b). Electron microscopy observations (FESEM) have shown rounded

193 sub-micrometric particles for disordered dolomite and rhombohedral micrometric particles for 194 ordered dolomite (see insets in Figure 2). These morphologies are not surprising results because 195 rounded sub-micrometric particles have been also identified from lab bio-assisted experiments at 196 low temperature (e.g. 2, 17, 23), and rhombohedral morphology is typical for ordered dolomite 197 from natural Earth systems or synthesized under hydrothermal conditions via mineral 198 replacement of calcite (e.g. 24). 
The Figure 2 summarizes the dolomite content as a function of temperature. The dolomite content was deduced from Rietveld refinements of XRD patterns. When high-carbonate alkalinity was used, the dolomite content in solid-products seems to be directly proportional to temperature from 100 to $200^{\circ} \mathrm{C}$. However, dolomite was not detected at 50 and $75^{\circ} \mathrm{C}$ for the same reaction duration. The dolomitization process is limited via simultaneous hydrothermal dissolution in high-purity water. In fact, small proportion of dolomite $(6 \%)$ was only determined at $200^{\circ} \mathrm{C}$ for a reaction duration of 90 days. Based on these exploratory results, we assume that formation of dolomite via simultaneous dissolution of calcite and magnesite is significantly co-promoted by temperature and high-carbonate alkalinity. We note that carbonate alkalinity has been suspected to increase significantly in bio-assisted dolomite synthesis at low temperature (e.g. $2,15-16)$ or in natural systems $(8,25)$; but, this parameter is not enough to promote alone the dolomite formation in abiotic systems at low temperature $\left(<100^{\circ} \mathrm{C}\right)$ via simultaneous dissolution of calcite and magnesite; probably, because both minerals remain stable in high-carbonate alkaline medium. However, this original result opens new possibilities to investigate dolomite formation in abiotic systems at low-temperature; obviously, by using soluble salts as $\mathrm{Ca}$ and $\mathrm{Mg}$ sources. Considering now that dolomite formation is promoted in high-carbonate alkaline medium therefrom $100^{\circ} \mathrm{C}$; complementary dolomitization experiments were performed at five different reaction durations $(5,13,21,42,60$ days $)$ and three different temperatures $\left(100,150\right.$ and $\left.200^{\circ} \mathrm{C}\right)$ in order to assess the dolomitization rate and reaction mechanism. In this way, two kinetic steps were clearly identified:

(I) Rapid proto-dolomite formation by simultaneous dissolution of calcite and magnesite (or disordered dolomite: absence of superstructure reflections 101, 015, 021, etc.), dominant in the first twenty days and positively correlated with temperature. In fact, the proto-dolomite is a 11 
nanocrystalline phase (see Figure 3) which contains a very high $\mathrm{Mg}$ atomic concentration

223 (>38\%), but an irregular intercalation between $\mathrm{Ca}$ and $\mathrm{Mg}$ into the crystals is only expected as 224 clearly determined by XRD (Fig. 4).

(II) Proto-dolomite to dolomite transformation, probably by coupled dissolutionrecrystallization process. This second step remains still an open question for dolomite formation in our experiments; but it seems dominant therefrom 20 days of reaction as clearly identified on experimental XRD patterns (see Figure 4). Based on XRD patterns and some TEM observations, we suggest that the so-called proto-dolomite is rapidly transformed to ordered dolomite; but, both crystalline phases can coexist as a function of time if $\mathrm{Ca}$ and $\mathrm{Mg}$ sources are still available. This is in agreement with a suspected overlapping in 104 peaks. Consequently, it is very difficult to determine if an evolution of the order degree exists during dolomite formation in our experiments.

The temporal variation of dolomite content was determined from Rietveld refinements of XRD patterns. These experimental kinetic data were then fitted by using a simple kinetic model (kinetic pseudo-second-order model) in order to estimate the initial reaction rate of dolomitization. Graphically, this initial rate is defined as the slope of the tangent line when the time tends toward zero on the "dolomite content versus time" curve (20). The results summarized in Table 2 reveal that the initial reaction rate of dolomitization and the maximum of dolomite content are positively correlated with temperature (see Figure 5 and Table 2). This temperature dependence suggests an agreement with Arrhenius law, that allows a simple estimation of activation energy $\left(E_{a}=29 \mathrm{~kJ} / \mathrm{mol}\right)$ for dolomitization reaction in our experiments. This value is about four times lower than the value of $133.3 \mathrm{~kJ} / \mathrm{mol}$ reported by Arvidson and Mackenzie (8-9).

The experimental configurations are not necessary comparable; however, we assume that the 12 
high-carbonate alkalinity decreases significantly the energetic barriers to form dolomite in a given system.

The results deduced from the Rietveld refinements of XRD patterns were compared with thermogravimetric (TG) measurements performed in $100 \% \mathrm{~N}_{2}$ or $\mathrm{CO}_{2}$ atmosphere. The results obtained from both analytical techniques are generally in agreement, except for lower dolomite contents in the solid products. Herein, the dolomite decomposition, concerning the first step $\left(\mathrm{CaMg}\left(\mathrm{CO}_{3}\right)_{2} \rightarrow \mathrm{MgO}+\mathrm{CaCO}_{3}\right)$ during heating process was systematically overlapped with magnesite decomposition in both gas atmospheres, magnesite decomposition starting at lower temperature. For this specific study, we assumed that Rietveld refinement of XRD patterns is better adapted to estimate the dolomite content in synthesized solids.

Calcite and magnesite could co-exist in various active natural media (sedimentary deposits, modern marine sediments, hydrothermal systems, deep geological formations...). Based on above results, the calcite-magnesite interactions in alkaline media (e.g. the Lost City field and Samail Ophiolite in Oman) could represent a potential source of dolomite. At the present time, this scenario has not been considered in geo-sciences to the best of our knowledge.

\section{Conclusion}

This study provides new experimental conditions to which dolomite can be formed in hydrothermal systems via simultaneous dissolution of calcite and magnesite. Herein, the dolomite formation was co-promoted by temperature and high-carbonate alkalinity. The activation energy for this reaction pathway $\left(\mathrm{CaCO}_{3}+\mathrm{MgCO}_{3} \rightarrow \mathrm{CaMg}\left(\mathrm{CO}_{3}\right)_{2}\right)$ is $29 \mathrm{~kJ} / \mathrm{mol}$. This reaction pathway has not been documented in the literature; however, it could be exist in deep geological formations and/or hydrothermal systems. In conclusion, this basic research opens new 13 
268 possibilities to investigate abiotic formation of dolomite at laboratory scale, probably towards the 269 abiotic formation of dolomite at low-temperature $\left(<100^{\circ} \mathrm{C}\right)$.

270

271

272

273

274

275

276

277

278

279

280

281

282

283

284 
285

286

287

288

289

290

291

292

293

294

295

296 297 298 299 300 301 302

304

305

306

\section{6}

\section{3}

\section{Acknowledgements}

The authors are grateful to the French National Center for Scientific Research (CNRS), the Univ.

Grenoble Alpes, the Labex OSUG@2020 and the ANR French research agency (ANR CORO and ANR SPRING projects) for providing financial support. .

\section{4}

95 


\section{References}

(1) McKenzie, J. A. The dolomite problem: an outstanding contraversy. In: Controversies in Modern Geology: Evolution of Geological Theories in Sedimentology (Eds D. W. Muller, J. A., McKenzie and H. Weissert) ,Academic Press, London 1991, p.37-54.

(2) Sanchez-Roman, M.; McKenzie, J. A.; Wagener, A-de-L. R.; Rivadeneyra, M. A.; Vasconcelos, C. Earth Planet. Sci. Lett, 2009, 285, 131.

(3) Mckenzie, J. A.; Vasconcelos, C. Sedimentology 2009, 56, 205.

(4) Deelman, J. C. Low-temperature formation of dolomite and magnesite, 2011, p. 211-273. http://www.jcdeelman.demon.nl/dolomite/bookprospectus.html

(5) Deelman, J. C. 2001, Chemie Der Erde-Geochemistry, 2001, 61, 224.

(6) Xu, J.; Yan, C. ; Zhang, F.; Konishi, H. ; Xu, H.; Teng, H. PNAS 2013, doi : 10.1073/pnas.1307612110.

(7) Compton, J. S. Geology, 1988, 16, 318.

(8) Arvidson, R. S.; Mackenzie, F. T. Aquatic Geochem. 1997, 2, 273.

(9) Arvidson, R. S.; Mackenzie, F. T. Amer. J. Sci.1999, 299, 257.

(10) Medlin, W. L. Amer. Min. 1959, 44, 979.

(11) Grover, J.; Kubanek, F. Amer. J. Sci. 1983, 283, 514.

(12) Dockal, J. Carbonates and Evaporites, 1988, 3, 125. 
(14) Warren, J. Earth-Sci. Reviews, 2000, 52, 1.

(15) Warthmann, R.; Van Lith, Y.; Vasconcelos, C.; McKenzie, J. A.; Karpoff, A. M. Geology, 2000, 28, 1091.

(16) Kenward, P. A.; Goldstein, R. H.; Gonzalez, L. A.; Roberts, J. A. Geobiology, 2009, 7, 556.

(17) Deng, S.; Dong, H.; Lv, G.; Jiang, H.; Yu, B.; Bishop, E. Chem. Geol. 2010, 278, 151.

(18) Krause, S.; Liebetrau, V.; Gorb. S.; Sanchez-Roman, M.; Mackenzie J. A.; Treude, T. Geology, 2012, 40, 587.

(19) Lippmann, F. Sedimentary carbonate minerals. 1973, Springer-Verlag, 228pp.

(20) Montes-Hernandez, G.; Fernandez-Martinez, A.; Renard, F. Cryst. Growth Des. 2009, 9, 336

(21) Montes-Hernandez, G.; Renard, F.; Chiriac, R.; Findling, N.; Toche, F. Crys. Growth 4567.

(22) Taut, T., Kleeberg, R.; Bergmann, J. Mater. Struct. 1998, 5, 57.

(23) Perri, E.; Tucker, M. E. Geology, 2007, 35, 207. Des. 2012, 12, 5233. 
Table 1. Summary of experimental conditions and mineral content in solid-products deduced from Rietveld refinements of XRD patterns

\begin{tabular}{|c|c|c|c|c|c|c|c|c|c|}
\hline \multirow[t]{2}{*}{ Run \# } & \multirow[t]{2}{*}{ Solid Reactants } & \multirow{2}{*}{$\begin{array}{c}\mathrm{t} \\
\text { days }\end{array}$} & \multirow{2}{*}{$\begin{array}{c}\mathrm{T} \\
\left({ }^{\circ} \mathrm{C}\right)\end{array}$} & \multirow[t]{2}{*}{ Solution } & \multicolumn{2}{|c|}{$\mathrm{pH}$} & \multicolumn{3}{|c|}{ Product amount $(\%)$ from XRD } \\
\hline & & & & & initial & final & Calcite & Magnesite & Dolomite \\
\hline $1^{*}$ & $\mathrm{CaCO}_{3}-\mathrm{MgCO}_{3}$ & 90 & 50 & HAS & 8.9 & 9.0 & 38 & 57 & 0 \\
\hline $2^{*}$ & $\mathrm{CaCO}_{3}-\mathrm{MgCO}_{3}$ & 90 & 75 & HAS & 8.9 & 9.1 & 47 & 49 & 0 \\
\hline $3^{*}$ & $\mathrm{CaCO}_{3}-\mathrm{MgCO}_{3}$ & 90 & 100 & HAS & 8.9 & 9.2 & 43 & 43 & 9 \\
\hline $4^{*}$ & $\mathrm{CaCO}_{3}-\mathrm{MgCO}_{3}$ & 90 & 150 & HAS & 8.9 & 9.3 & 26 & 40 & 30 \\
\hline $5^{* *}$ & $\mathrm{CaCO}_{3}-\mathrm{MgCO}_{3}$ & 90 & 200 & HAS & 8.9 & $8.0^{\mathrm{a}}$ & 11 & 4 & 49 \\
\hline 6 & $\mathrm{CaCO}_{3}-\mathrm{MgCO}_{3}$ & 90 & 50 & $\mathrm{PW}$ & $\approx 6.5$ & 10.3 & 61 & 37 & 0 \\
\hline 7 & $\mathrm{CaCO}_{3}-\mathrm{MgCO}_{3}$ & 90 & 75 & PW & $\approx 6.5$ & 10.2 & 47 & 52 & 0 \\
\hline 8 & $\mathrm{CaCO}_{3}-\mathrm{MgCO}_{3}$ & 90 & 100 & PW & $\approx 6.5$ & 10.0 & 49 & 50 & 0 \\
\hline 9 & $\mathrm{CaCO}_{3}-\mathrm{MgCO}_{3}$ & 90 & 150 & PW & $\approx 6.5$ & 9.6 & 27 & 72 & 0 \\
\hline 10 & $\mathrm{CaCO}_{3}-\mathrm{MgCO}_{3}$ & 90 & 200 & PW & $\approx 6.5$ & 9.0 & 54 & 39 & $6^{\mathrm{b}}$ \\
\hline 11 & $\mathrm{CaCO}_{3}-\mathrm{MgCO}_{3}$ & 5 & 150 & HAS & 8.9 & 9.1 & 44 & 45 & 9 \\
\hline 12 & $\mathrm{CaCO}_{3}-\mathrm{MgCO}_{3}$ & 13 & 150 & HAS & 8.9 & 9.2 & 56 & 25 & 13 \\
\hline 13 & $\mathrm{CaCO}_{3}-\mathrm{MgCO}_{3}$ & 21 & 150 & HAS & 8.9 & 9.2 & 39 & 42 & 16 \\
\hline 14 & $\mathrm{CaCO}_{3}-\mathrm{MgCO}_{3}$ & 42 & 150 & HAS & 8.9 & 9.3 & 28 & 38 & 26 \\
\hline 15 & $\mathrm{CaCO}_{3}-\mathrm{MgCO}_{3}$ & 60 & 150 & HAS & 8.9 & 9.4 & 28 & 34 & 28 \\
\hline 16 & $\mathrm{CaCO}_{3}-\mathrm{MgCO}_{3}$ & 5 & 200 & HAS & 8.9 & 9.2 & 34 & 37 & 24 \\
\hline 17 & $\mathrm{CaCO}_{3}-\mathrm{MgCO}_{3}$ & 13 & 200 & HAS & 8.9 & 9.1 & 29 & 40 & 26 \\
\hline 18 & $\mathrm{CaCO}_{3}-\mathrm{MgCO}_{3}$ & 21 & 200 & HAS & 8.9 & 9.2 & 39 & 30 & 28 \\
\hline 19 & $\mathrm{CaCO}_{3}-\mathrm{MgCO}_{3}$ & 42 & 200 & HAS & 8.9 & 9.1 & 16 & 26 & 50 \\
\hline 20 & $\mathrm{CaCO}_{3}-\mathrm{MgCO}_{3}$ & 60 & 200 & HAS & 8.9 & 9.2 & 14 & 21 & 52 \\
\hline 21 & $\mathrm{CaCO}_{3}-\mathrm{MgCO}_{3}$ & 5 & 100 & HAS & 8.9 & 9.1 & 46 & 47 & 3 \\
\hline 22 & $\mathrm{CaCO}_{3}-\mathrm{MgCO}_{3}$ & 20 & 100 & HAS & 8.9 & 9.0 & 47 & 45 & 6 \\
\hline
\end{tabular}


Table 2. Summary of kinetic parameters for dolomite formation via simultaneous dissolution of calcite and magnesite in high-carbonate alkaline medium.

\begin{tabular}{c|cccc}
\hline $\begin{array}{c}\text { Temperature } \\
\left({ }^{\circ} \mathrm{C}\right)\end{array}$ & $\begin{array}{c}\xi_{\text {extent, } \max } \\
(\%)\end{array}$ & $\begin{array}{c}t_{1 / 2} \\
\text { days }\end{array}$ & $\begin{array}{c}v_{0} \\
1 / \text { days }\end{array}$ & $\begin{array}{c}\mathrm{E}_{\mathrm{a}} \\
\mathrm{kJ} / \mathrm{mol}\end{array}$ \\
\hline \multicolumn{7}{c}{$\mathrm{CaCO}_{3}+\mathrm{MgCO}_{3} \rightarrow \mathrm{CaMg}\left(\mathrm{CO}_{3}\right)_{2}$} \\
\hline 100 & 10.7 & 17.8 & $\mathbf{6 . 0 1 \times 1 0 ^ { - 3 }}$ & 29 \\
150 & 38.5 & 23.8 & $1.61 \times 10^{-2}$ & \\
200 & 59.4 & 13.5 & $4.40 \times 10^{-2}$ & \\
\hline
\end{tabular}

$351 \xi_{\text {extent,max }}$ is the maximum value of dolomite content at apparent equilibrium and $t_{1 / 2}$ is the half-

352 content time determined by using a kinetic pseudo-second-order model. $v_{0}$ is the initial reaction

353 rate $\left(v_{0}=\xi_{\text {extent,max }} / t_{1 / 2} * 100\right)$. $\mathrm{E}_{\mathrm{a}}$ : activation energy determined by Arrhenius equation 354 (conventional linear form).

355

356

357

358

359

360

361

362 


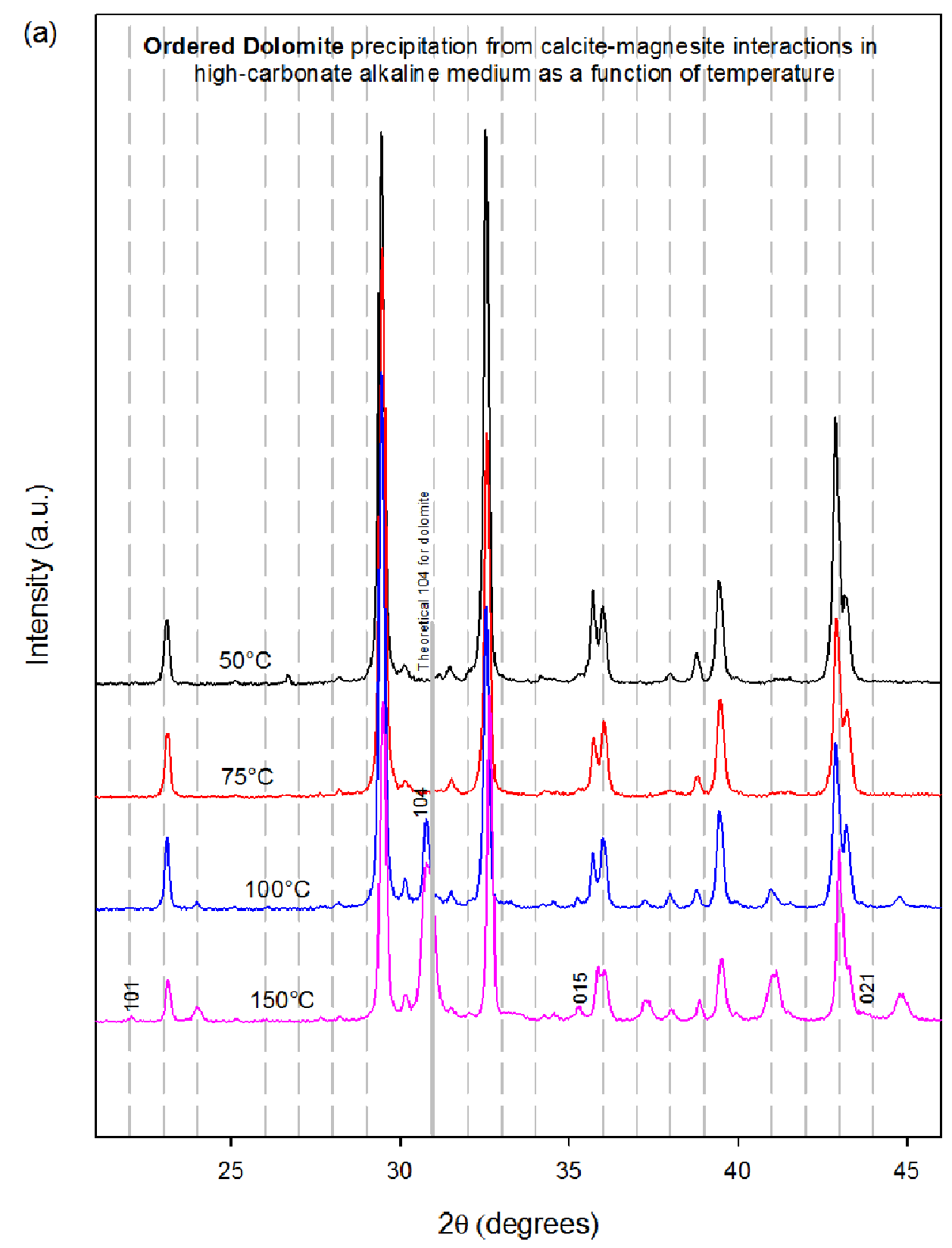

364 Figure 1. Experimental XRD patterns for dolomite precipitation via simultaneous dissolution of 365 calcite and magnesite. 101, 015 and 021 are typical superstructure reflections for dolomite in the 366 20-45 2th range (ICDD 036-0426). Influence of temperature and nature of interacting fluid. (a) 367 reaction in high-carbonate alkaline solution and (b) in high-purity water. 


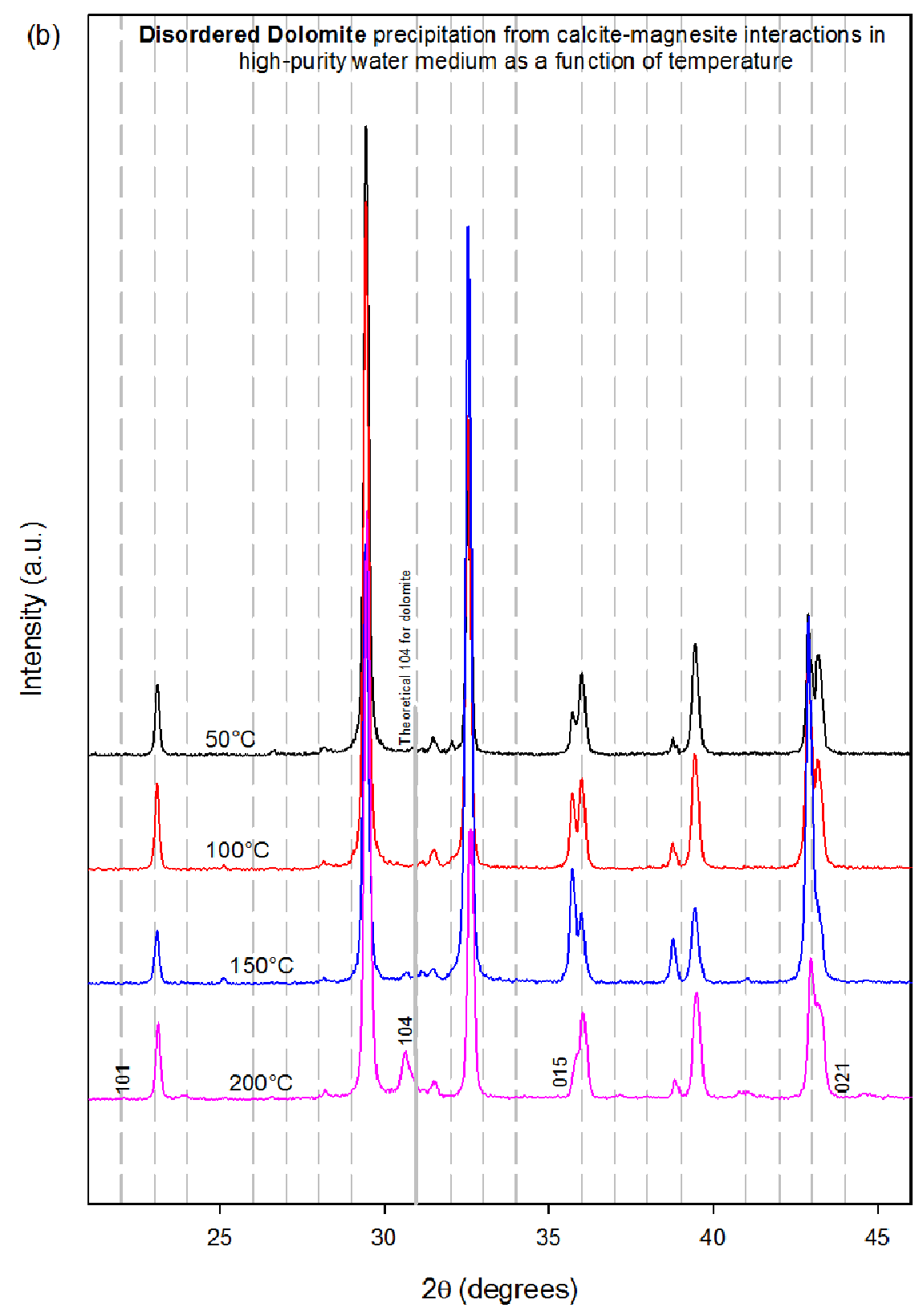

$370 \quad$ Figure 1 (b) 


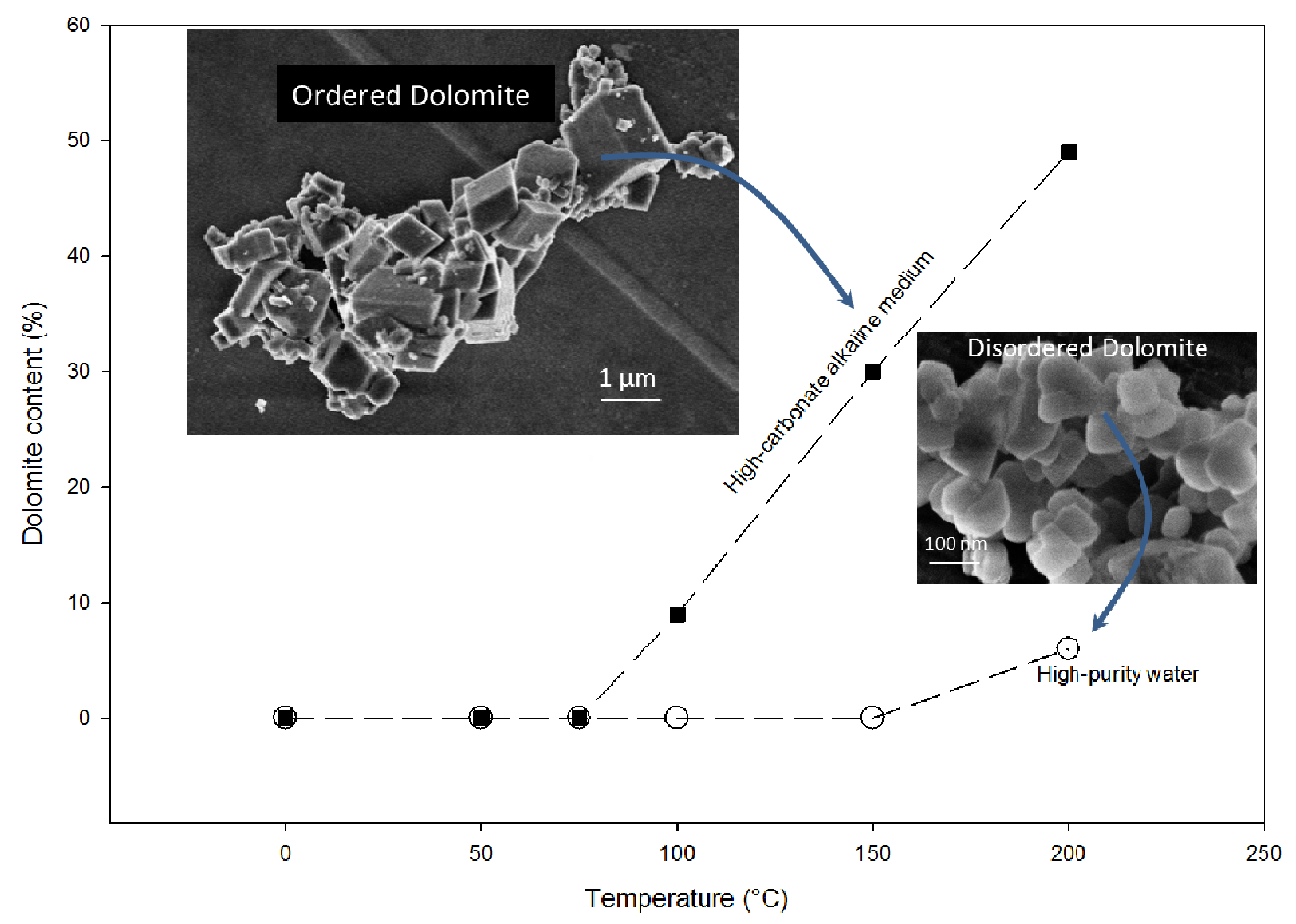

375 Figure 2. Dolomite content behavior as a function of temperature for two different initial 376 interacting fluids (high-carbonate alkaline solution and high-purity water). Dolomite content was 377 deduced from Rietveld refinement of XRD patterns shown in Fig. 1. Insets: FESEM micro378 images showing ordered and disordered dolomite morphologies. 


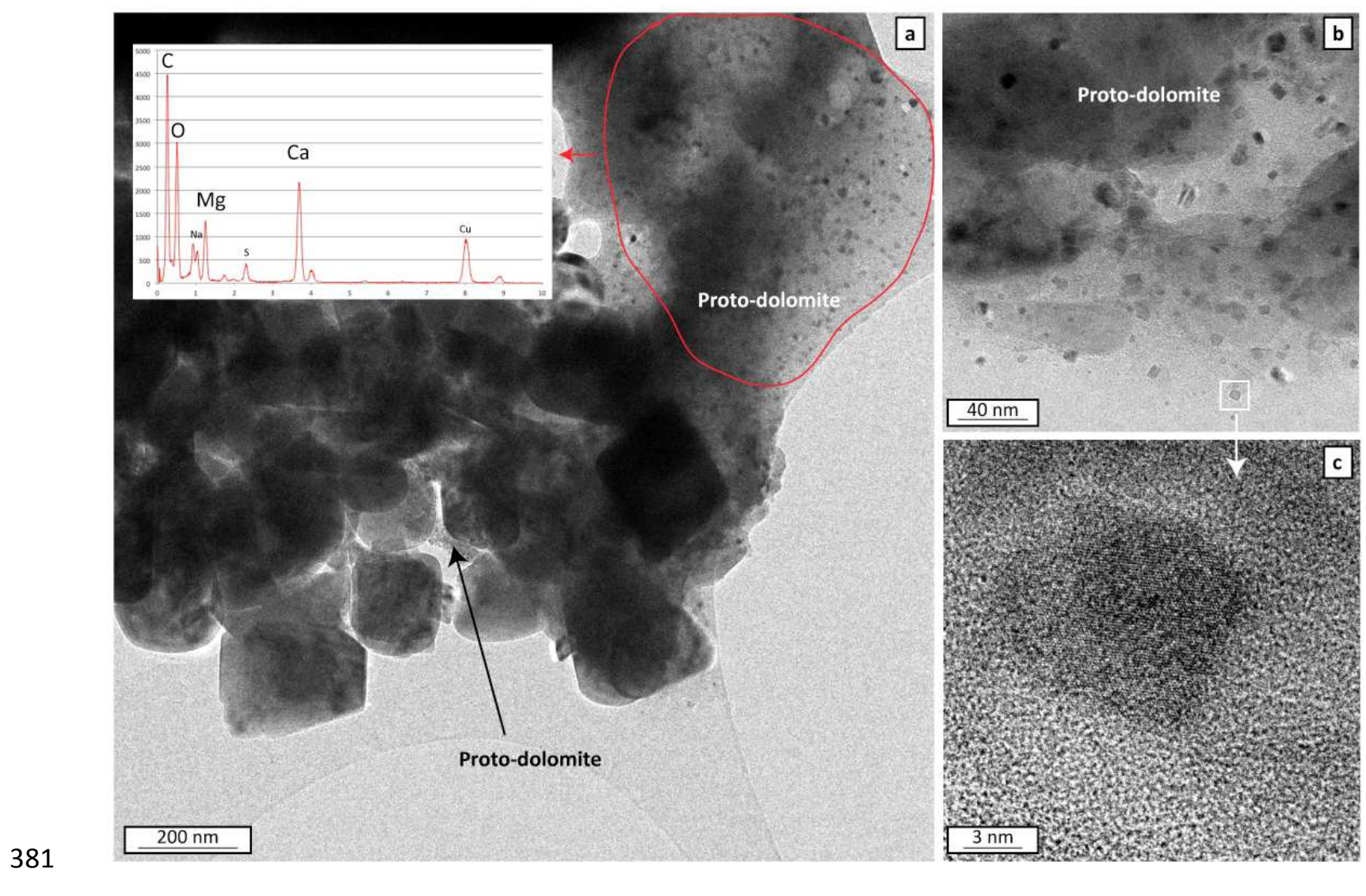

384 Figure 3. Bright field image of a) proto-dolomite mixed with calcite and magnesite grains (from 385 run 16) (inset: EDS spectrum extracted from STEM chemical mapping), magnification of proto386 dolomite where nanoparticles are scattered in an amorphous gel, c) high-resolution of a 387 crystalline nano-particle. 


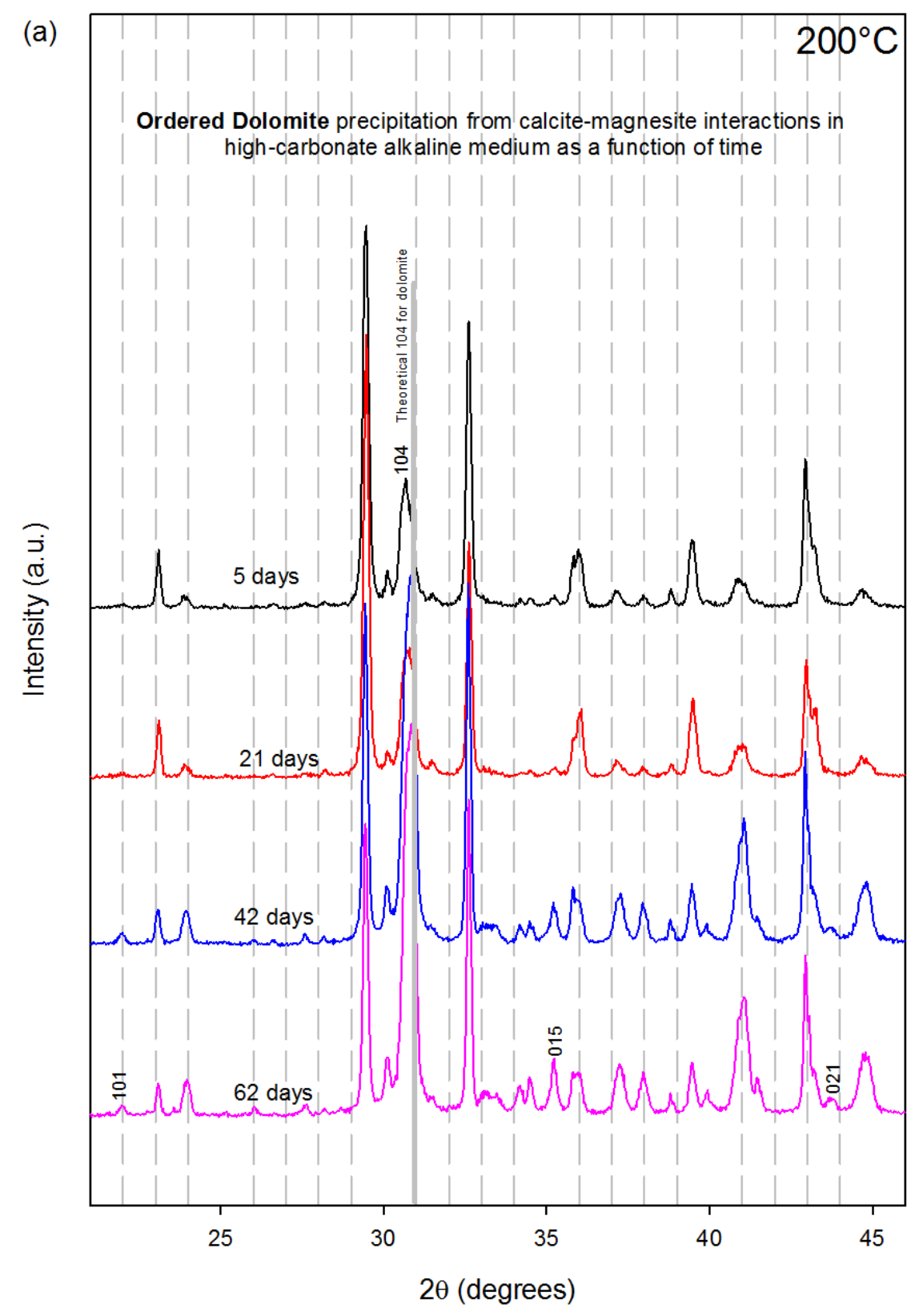

392 Figure 4. Experimental XRD patterns for dolomite precipitation via simultaneous dissolution of 393 calcite and magnesite. 101, 015 and 021 are typical superstructure reflections for dolomite in the 394 20-45 2th range (ICDD 036-0426). Kinetic behavior at (a) $200^{\circ} \mathrm{C}$ and (b) $150^{\circ} \mathrm{C}$. 


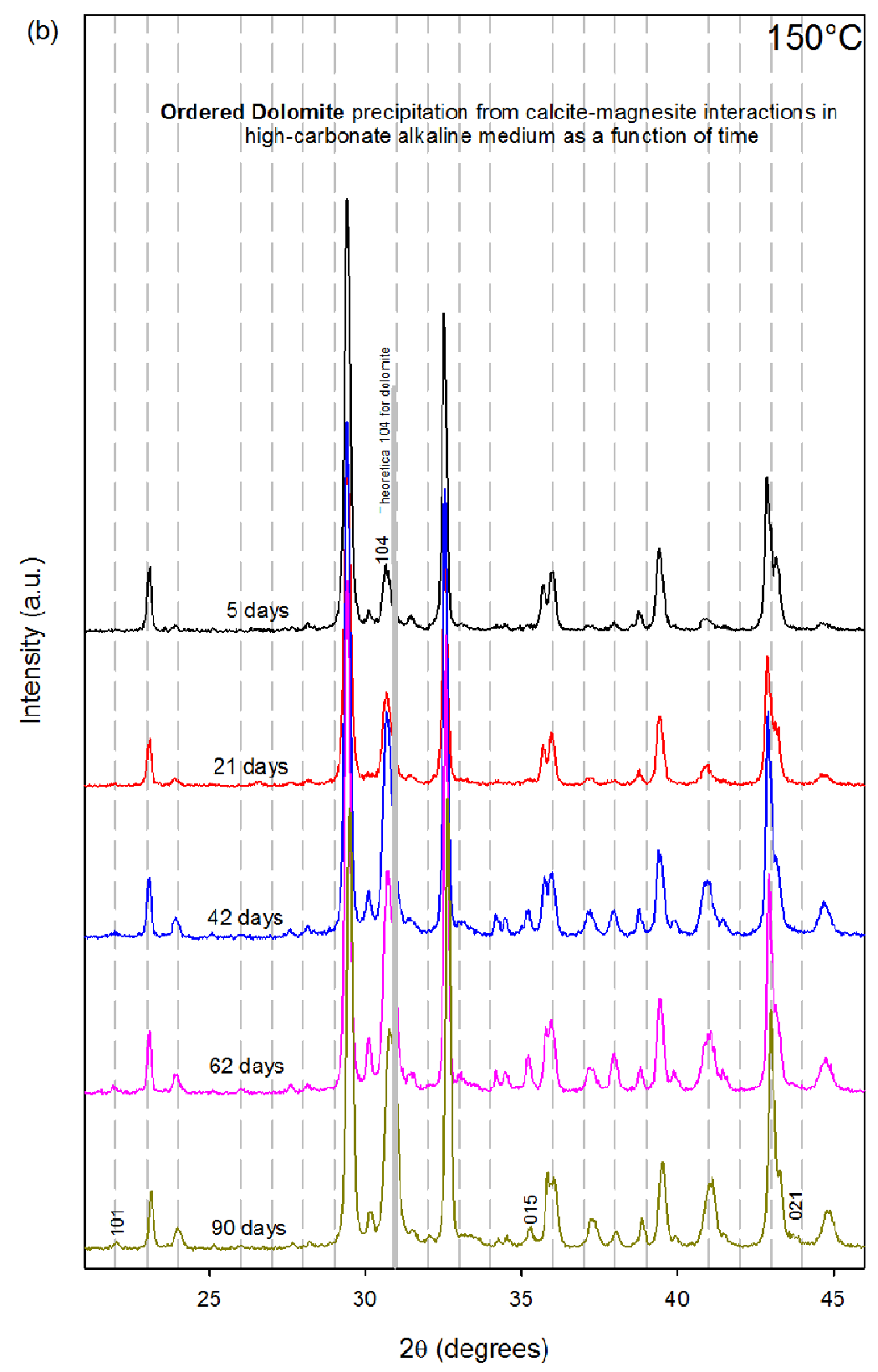

396

$397 \quad$ Figure 4 (b) 


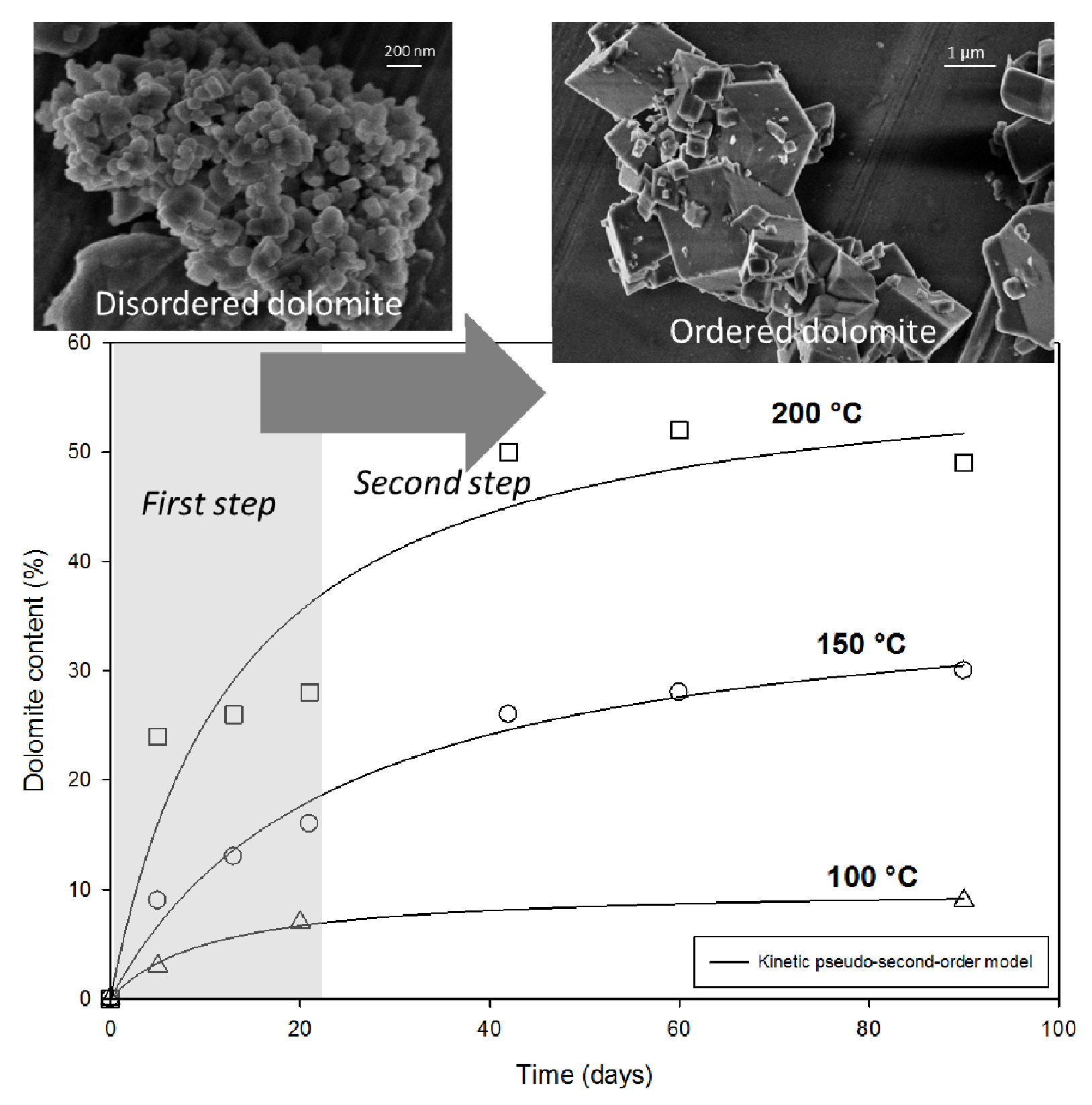

400

401 Figure 5. Temperature influence on the kinetic of dolomite formation via simultaneous 402 dissolution of calcite and magnesite in high-carbonate medium. Dolomite content was deduced 403 from Rietveld refinement of XRD patterns shown in Fig. 3. Insets: FESEM micro-images show 404 that disordered dolomite is firstly formed followed by the formation of ordered dolomite (slower 405 step). 
407 Precipitation of ordered dolomite via simultaneous dissolution of calcite and magnesite: 408 New experimental insights into an old precipitation enigma by Montes-Hernandez et al.

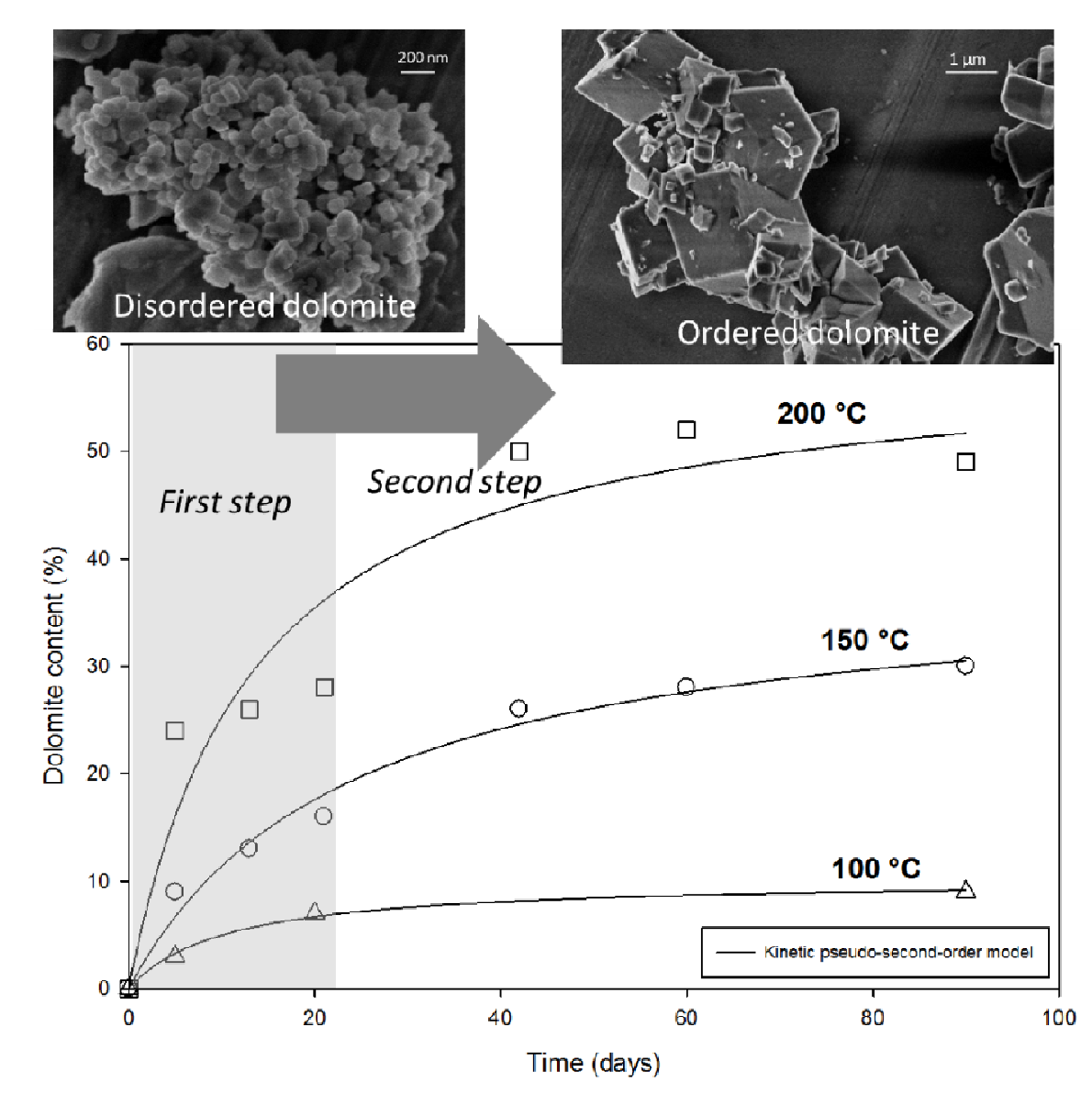

Synopsis: This study provides new experimental conditions to which dolomite can be formed in 413 hydrothermal systems via simultaneous dissolution of calcite and magnesite. Herein, the dolomite 414 formation was co-promoted by temperature and high-carbonate alkalinity. The activation energy 415 for this reaction pathway ( ) is $29 \mathrm{~kJ} / \mathrm{mol}$. 